\title{
The Relative Contributions of Seed Bank, Seed Rain, and Understory Vegetation Dynamics to the Reorganization of Tsuga Canadensis Forests After Loss due to Logging or Simulated Attack by Adelges tsugae
}

\section{Citation}

Farnsworth, Elizabeth J., Audrey A. Barker Plotkin, Aaron M. Ellison. 2012. The relative contributions of seed bank, seed rain, and understory vegetation dynamics to the reorganization of Tsuga canadensis forests after loss due to logging or simulated attack by Adelges tsugae. Canadian Journal of Forest Research 42(12): 2090-2105.

\section{Published Version}

doi:10.1139/cjfr-2012-0305

\section{Permanent link}

http://nrs.harvard.edu/urn-3:HUL.InstRepos:10459024

\section{Terms of Use}

This article was downloaded from Harvard University's DASH repository, and is made available under the terms and conditions applicable to Other Posted Material, as set forth at http:// nrs.harvard.edu/urn-3:HUL.InstRepos:dash.current.terms-of-use\#LAA

\section{Share Your Story}

The Harvard community has made this article openly available. Please share how this access benefits you. Submit a story. 
1 The relative contributions of seed bank, seed rain, and understory vegetation dynamics to

2 the reorganization of Tsuga canadensis forests after loss due to logging or simulated attack

5 Elizabeth J. Farnsworth

6 New England Wild Flower Society

7180 Hemenway Road, Framingham, Massachusetts 01701 USA

8 Email: efarnswo@mtholyoke.edu

9

10 Audrey A. Barker Plotkin

11 Harvard Forest, Harvard University

12324 North Main Street, Petersham, Massachusetts 01366

13 Email: aabarker@fas.harvard.edu

14

15 Aaron M. Ellison*

16 Harvard Forest, Harvard University

17324 North Main Street, Petersham, Massachusetts 01366

18 Email: aellison@fas.harvard.edu

19

$20 *$ Author for correspondence

21

22 
23 Abstract: Profound changes are occurring in forests as native insects, nonnative insects, or

24 pathogens irrupt on foundation tree species; comprehensive models of vegetation responses are

25 needed to predict future forest composition. We experimentally simulated hemlock woolly

26 adelgid (Adelges tsugae Annand) infestation (by girdling trees) and preemptive logging of

27 eastern hemlock (Tsuga canadensis [L.] Carrière), and compared vegetation dynamics in

28 replicate $90 \times 90-\mathrm{m}$ treatment plots and intact hemlock stands from 2004-2010. Using Chao-

29 Sørensen abundance-based similarity indices, we assessed compositional similarities of trees,

30 shrubs, forbs, and graminoids among the seed bank, seed rain, and standing vegetation over time

31 and among treatments. Post-treatment seed rain, similar among treatments, closely reflected

32 canopy tree composition. Species richness of the seed bank was similar in 2004 and 2010.

33 Standing vegetation in the hemlock controls remained dissimilar from the seed bank, reflecting

34 suppressed germination. Recruits from the seed rain and seed bank dominated standing

35 vegetation in the logged treatment, whereas regeneration of vegetation from the seed bank and

36 seed rain was slowed due to shading by dying hemlocks in the girdled treatment. Our approach

37 uniquely integrates multiple regeneration components through time and provides a method for

38 predicting forest dynamics following loss of foundation tree species. 


\section{Introduction}

41 A key aim of forest ecology is to elucidate factors that influence transitions of plants

42 from the seed to the canopy under a range of management conditions. Changes in forest species

43 composition through time are driven by several factors, including recruitment from the seed

44 bank, inputs from seed rain, interactions with standing vegetation, variable edaphic and climatic

45 conditions, and a range of mortality agents including insects and pathogens (Lovett et al. 2006;

46 Burton et al. 2011). Long-term, integrative studies of these ecological factors are needed to

47 predict the species composition of future forests, especially as herbivores irrupt and pathogens

48 become more prevalent. Pathogens and insects can damage or eliminate dominant and

49 foundation tree species (sensu Ellison et al. 2005), rapidly and radically altering the composition

50 of forest stands. Silvicultural practices and preemptive measures such as logging, undertaken to

51 remove vulnerable and/or economically valuable tree species before an infestation or infection

52 occurs, also affect seed-banking, regeneration, and forest dynamics (Graae and Sunde 2000;

53 Decocq et al. 2004).

$54 \quad$ Eastern hemlock (Tsuga canadensis [L.] Carrière) forests provide a model system in

55 which to examine these dynamics, specifically comparing responses to preemptive hemlock

56 logging or infestation by the hemlock woolly adelgid (Adelges tsugae [Annand]). Intact, mature

57 hemlock forests tend to be stable and long-lived, with depauperate understories suppressed by a

58 very shady microenvironment and acidic needle litter (Catovsky and Bazzaz 2000; D'Amato et

59 al. 2008). Palynological data illustrate that hemlock forests underwent a region-wide decline

$60 \sim 5400$ years ago caused by a combination of insect-driven defoliation and climatic change, but

61 they recovered to their current extent after 300-1200 years (Foster et al. 2006). 
A similar process has been unfolding in the last 30 years. The hemlock woolly adelgid

63 has been spreading rapidly since the 1980s, defoliating trees and causing more than $95 \%$

64 mortality in parts of its range (Orwig et al. 2008). Preemptive salvage logging has occurred in

65 many hemlock stands to extract economic value before the adelgid infests and kills the trees

66 (Foster and Orwig 2006). Slow loss of living hemlock due to the adelgid acts as a gradually

67 changing filter on vegetation recruitment, progressively suffusing the understory with light,

68 stimulating seed germination, and creating opportunities for plant colonization. For example,

69 Yorks et al. (2003) documented gradually increasing abundance of Betula, Acer, and four

70 monilophyte species in the five years following a hemlock girdling treatment.

71 In contrast, logging removes the canopy suddenly, greatly increasing light availability at

72 the forest floor in a single pulse (Krasny and Whitmore 1992). Logging also often leaves a large

73 amount of slowly-decomposing slash that initially suppresses regeneration, and effects of rutting,

74 scarification, and other disturbances can persist in second-growth hemlock stands (Smith 1986).

75 In either case, the composition of the forest eventually increases in species richness, with new

76 broad-leaved tree species coming to predominate in even-aged stands (Orwig and Foster 1998).

77 However, the near-term composition of the recovering forest is difficult to predict; stochastic

78 dynamics, coupled with a warming climate that favors increased herbivory or recruitment of

79 plant species adapted to warmer climate conditions (Paradis et al. 2008), may cause novel

80 assemblages to form (e.g., Spaulding and Rieske 2010).

81 In this paper, we present results of a seven-year study that documents species present in

82 the seed bank, seed rain, and tree, sapling, seedling, and herbaceous vegetation before and after

83 hemlock-dominated stands were subjected to three experimental treatments: (1) simulated attack

84 by A. tsugae; (2) preemptive logging; and (3) intact control. We ask four specific questions: 
85 1. To what extent are the initial compositions of the seed bank, seed rain, canopy, and 86 existing forest-floor species similar? Comparative studies frequently report disparities

87 among the plant species compositions of the seed bank, seed rain, and standing vegetation (Hopfensperger 2007). Such disparities pose challenges for predicting future forest composition, but can also indicate the most important ecological filters operating on particular species, life forms, and life stages (Myers and Harms 2011). Based on previous studies, we expected to find little concordance in species composition among 92 these regeneration components.

93 2. Do the compositions of the seed bank, seed rain, canopy, sapling, seedling, and more closely reflect the inputs of seed rain and the seed bank as the girdled canopy gradually ceased acting as a strong filter on germination and establishment of seedlings. We also expected the 2010 seed bank to diverge in composition from the 2004 seed bank in the logged treatment as new seed sources became available and the existing bank became depleted as seeds germinated and recruited to the seedling layer.

101 3. Does the vegetation composition differ between stands undergoing mortality due to simulated adelgid attack versus logging, and how does post-disturbance composition compare with intact stands? We predicted that seed rain would continue to supply new recruits as the canopy slowly died in the girdled treatment, while the upper layer $(0-10$ $\mathrm{cm}$ depth) of the forest seed bank would contribute most of the new recruits in newly logged stands, as it would be most responsive to scarification during skidder activity. We also expected the composition of the vegetation on the forest floor to remain stable and 

comprehensive profile of changing assemblages of forest plants. treatment (Catovsky and Bazzaz 2002). standing vegetation may converge in similarity.

dominated by shade-tolerant $T$. canadensis in the heavily shaded hemlock control

4. Can we use these data to predict stand composition as post-hemlock succession proceeds? The advance regeneration afforded by sapling, shrub, and herbaceous layers, plus ongoing seed rain, should dominate the vegetation that develops in post-treatment years. Figure 1 depicts a simple, conceptual null model in which these inputs contribute equally to outcomes in stand composition. Observed departures from this model, reflected in different treatment responses, would reflect contrasting ecological filters imposed by processes such as insect or pathogen damage and logging. Although we anticipated that the composition of the standing vegetation would differ between adelgid-impacted and logged stands during early phases of stand regeneration, over much longer terms, Prior studies of regeneration in logged or adelgid-infested hemlock stands separately have documented changes in plant species composition (Orwig et al. 2008), provided baseline data on seed bank and understory vegetation (Catovsky and Bazzaz 2000; Yorks et al. 2000; Sullivan and Ellison 2006), or used successional data to inform predictive models of tree species abundance (Spaulding and Rieske 2010); ours is the first to integrate all these types of data with information on temporal dynamics of seed bank and seed rain compositions in an experimental context. Most previous plot-based studies have tended to focus on single guilds, such as forestfloor herbs (Burton et al. 2011), or examined ecosystems other than temperate forests (e.g., Drake 1998); we document the emergence of both herbaceous and woody vegetation to present a 


\section{Methods}

\section{Harvard Forest Hemlock Removal Experiment}

This study took place in the Harvard Forest Hemlock Removal Experiment (HF-HeRE)

134 plots, located within the 121-ha Simes Tract at the Harvard Forest Long-Term Ecological

135 Research Site in Petersham, Massachusetts, USA $\left(42.47^{\circ}-42.48^{\circ} \mathrm{N}, 72.22^{\circ}-72.21^{\circ} \mathrm{W}\right.$; elevation

136 215-300 m a.s.1.). The Harvard Forest lies within the hemlock/hardwood/white pine transition

137 forest region of eastern North America, and the Simes Tract itself is classified as "hemlock-

138 hardwoods" (Kernan 1980). The soils are predominantly coarse-loamy, mixed, active, mesic

139 Typic Dystrudepts in the Charlton Series that are derived from glacial till (USDA n.d.). Prior to

140 the experimental treatments described below, eastern hemlock comprised 50-69\% of the (on

141 average) $50 \mathrm{~m}^{2} \mathrm{ha}^{-1}$ (mean) basal area, and $55-70 \%$ of the mean $875 \mathrm{stems} \mathrm{ha}^{-1}$ (Sullivan and

142 Ellison 2006). Other species that comprised $>10 \%$ of the initial basal area in any of the plots

143 included white pine (Pinus strobus L.), black birch (Betula lenta L.), red oak (Quercus rubra L.),

144 and red maple (Acer rubrum L.).

145 Full methods and diagrams of the HF-HeRE are given in Ellison et al. (2010); salient

146 details are presented here. Canopy-level manipulations were performed in two $90 \times 90 \mathrm{~m}(0.81$

147 ha) plots in each of two blocks; an additional 0.81 ha plot in each block served as a control.

148 Blocks were chosen based on their size and capacity to accommodate 3 large treatment plots

149 without edge effects. The "valley" block is in undulating terrain bordered on its northern edge

150 by a Sphagnum-dominated wetland, whereas the "ridge" block is on a forested ridge (see site

151 map in Ellison et al. 2010). Blocks and plots were sited and established in 2003. Within each

152 block, the two treatment plots and the intact control plot were located within $300 \mathrm{~m}$ of each

153 other, with similar topography and aspect. In 2003, A. tsugae was not present in any of the 
154 blocks; as of 2010, the insect was gradually colonizing hemlock stands at the Harvard Forest and 155 was present throughout the Simes Tract, but not yet causing hemlock mortality.

156 The first canopy manipulation, girdling, was designed to induce the gradual physical 157 decline (i.e., defoliation, biomass loss) caused by A. tsugae infestation. In this treatment, all 158 hemlock seedlings, saplings, and mature trees were girdled using knives or chainsaws over a 159 two-day period in early May 2005. The girdled hemlocks died over the course of the next two 160 years, and since have been slowly disintegrating in a pattern quite analogous to that observed 161 following heavy A. tsugae infestations (see also Yorks et al. 2003).

162 The second treatment, logging, was designed to mimic the effects of a commercial 163 hemlock-salvage operation involving removal of merchantable timber, pulp, and cordwood of 164 hemlock and other species (e.g., Pinus strobus L. and Quercus rubra L.). We applied a fixed165 diameter-limit cut. Between 65 and $70 \%$ of the stand basal area, including all T. canadensis 166 trees $>20 \mathrm{~cm}$ diameter (at breast height, $1.3 \mathrm{~m}$ ) and at least half of the merchantable white pine 167 and hardwoods (maple, birch, oaks), was harvested by chainsaw and removed from the two plots 168 using a rubber-tired skidder between February and April 2005 when the ground was frozen. The 169 third plot in each block was left intact, to serve as a T. canadensis control.

170 In this paper, we focus on species composition and abundance before treatments were 171 applied in 2005 and vegetation regeneration and reorganization for five years following the 172 hemlock removal treatments. Data on microclimate, stand structure, litterfall, coarse woody 173 debris, distribution and abundance of ants, beetles, and spiders, and fluxes of carbon and nitrogen 174 also were collected for two years prior to the 2005 treatment and are reported elsewhere (Sackett 175 et al. 2011; Lustenhouwer et al. 2012; Orwig et al. in review). Overall, changes in these variables 176 in the girdled treatment have been similar in pace and magnitude to those resulting from adelgid 
177 invasion throughout New England. For example, light availability increased gradually over time

178 in the girdled treatment (as in Yorks et al. 2003) but abruptly in the logged treatment

179 (Lustenhouwer et al. 2012). Average daily soil and air temperatures in the logged and girdled

180 treatments are $2-4{ }^{\circ} \mathrm{C}$ warmer in summer and cooler in winter relative to the hemlock control

181 plots, and both diurnal and seasonal variances in temperatures are highest in the logged treatment

182 (Lustenhouwer et al. 2012). Decline and loss of eastern hemlock in the logged and girdled

183 treatments at HF-HeRE also have led to reductions in overstory densities and basal area

184 comparable to those seen in sites long infested by the adelgid (Orwig and Foster 1998; Orwig et

185 al. 2002) or that have been salvage-logged (Kizlinski et al. 2002).

187 Composition of the seed rain

188 To characterize the composition of the seed rain, seeds were manually removed from

189 litter collected in five litterfall baskets that were placed at random coordinates throughout each

$19090 \times 90 \mathrm{~m}$ plot. Baskets $(40.6 \mathrm{~cm}$ long $\times 33 \mathrm{~cm}$ wide $\times 25.4 \mathrm{~cm}$ deep $)$ were constructed of

191 Sterilite ${ }^{\circledR}$ plastic with vent and drainage holes, and lined with no-see-um cloth $(0.25 \mathrm{~mm}$ mesh $)$

192 that was fastened to the edges with clips and suspended slightly above the bottom of the basket

193 to keep the litter dry. Replicate baskets were placed in the field at the beginning of September

1942005 , and material was collected quarterly in early April, mid-June, mid-October, and early

195 December of each year. Samples were air-dried and seeds separated. Seeds were identified to

196 species (when possible; to genus when not) using dichotomous keys in Montgomery (1977);

197 vouchers are stored in the Harvard Forest Herbarium. Representative individual seeds of each

198 species were weighed, and numbers of seeds in each sample were determined from the mass of

199 total samples (Greene and Johnson 1994). 


\section{Composition of the seed bank}

202 In June 2004, we marked five randomly-chosen points in the center $30 \times 30 \mathrm{~m}$ subplot of

203 each of the experimental treatment plots (to avoid edge effects), and collected a single $60 \mathrm{~cm} \times$

$20460 \mathrm{~cm} \times 20 \mathrm{~cm}$-deep soil monolith at each point (Sullivan and Ellison 2006). In May 2010, we

205 returned to the same points, chose a new sample location within $2 \mathrm{~m}$ of the original location, and

206 collected a single $15 \mathrm{~cm} \times 15 \mathrm{~cm} \times 20 \mathrm{~cm}$-deep soil core at each point. In both years, we

207 returned the soil cores within five hours to the lab for planting. In both 2004 and 2010, all cores

208 were trimmed to $10 \mathrm{~cm} \times 10 \mathrm{~cm} \times 20 \mathrm{~cm}$-deep blocks, and then sliced into 2 -cm depth

209 increments. These samples were placed into separate $7.5 \times 7.5 \mathrm{~cm}$ cells in a divided potting tray,

210 each cell first lined with a $1 \mathrm{~cm}$ deep layer of milled sphagnum to facilitate drainage. One

211 replicate reference cell for each of the cores was filled entirely with milled sphagnum and

212 monitored for recruitment of "weedy" species present in the greenhouse seed rain. All trays

213 were placed in the Harvard Forest greenhouse at full light, watered twice daily, and fertilized

214 once during each growing season with $1.7 \mathrm{~g} / \mathrm{L}$ of 20:20:20 fertilizer (J. R. Peters, Inc.,

215 Allentown, Pennsylvania, USA). Trays were randomly repositioned twice during each growing

216 season.

217 Seed bank composition was assessed using the direct germination method, without prior

218 sieving. Opinions differ in the literature about the relative merits of direct germination versus

219 seed extraction by suspension and filtering of seeds in water for characterizing the seed bank.

220 Studies comparing these methods have indicated that seed extraction can be ineffective for

221 detecting small-seeded species and overestimates the viable seed bank because it does not

222 distinguish non-viable seeds (Price et al. 2010). With the caveat that the direct germination 
223 approach also can discriminate against seeds not adapted for greenhouse conditions, we selected

224 this method as a more reliable estimator of seeds available for regeneration in the field treatment

225 plots. Trays were monitored on a weekly to biweekly basis from June to September in both 2004

226 and 2010; after September, no new germination occurred and existing seedlings were senescing.

227 Most newly-emerging seedlings were removed to prevent competition with later-emerging

228 plants, except where removal would disturb existing, as-yet-unidentified seedlings. Unidentified

229 specimens were out-planted to larger pots in September of year 1 (2004 or 2010) to ensure that

230 root-binding would not cause death or affect their growth in year 2 (2005 or 2011). Specimens

231 still unidentified at the end of the first growing season were hardened off and watered bi-weekly

232 from November to April, during which time greenhouse temperatures were kept at $4{ }^{\circ} \mathrm{C}$.

233 Surviving seedlings were monitored throughout the second growing season (i.e., summers 2005

234 and 2011) until reproduction occurred or until plants were mature enough to identify

235 unambiguously. Haines (2011) was used for identifications and nomenclature, and Jenkins et al.

236 (2008) provided confirmation on species presence at Harvard Forest. Vouchers are stored in the

237 Harvard Forest Herbarium.

239 Composition of the standing vegetation

240 In 2003 , two $30 \mathrm{~m}$ transects were established, running through the center $30 \mathrm{~m} \times 30 \mathrm{~m}$ of

241 each plot, for the purposes of sampling the forest-floor vegetation. Five $1 \mathrm{~m}^{2}$ subplots were

242 spaced evenly along each transect. Transects were permanently marked with stakes, and

243 subplots were marked at the northwest corner with flags. Percent covers of herbaceous species,

244 shrubs, and tree seedlings ( $<1.3 \mathrm{~m}$ tall) were estimated, and numbers of tree seedlings were

245 counted in each subplot in July of each year. Saplings, defined as trees $>1.3 \mathrm{~m}$ tall but with 
$246 \mathrm{DBH}<5 \mathrm{~cm}$, were identified to species, and all saplings in the $30 \mathrm{~m} \times 30 \mathrm{~m}$ central plot were

247 counted in 2004, 2007 and 2009. Canopy trees (minimum size: $5 \mathrm{~cm} \mathrm{DBH)} \mathrm{in} \mathrm{the} \mathrm{entire} 90 \times 90$

248 m plot were identified, mapped, and labeled with numbered aluminum tags. Size (DBH) and

249 status (living/dead) was recorded in 2004 and 2009. Additional observations of plants within 3

$250 \mathrm{~m}$ of the seed-bank core locations were made in May and August 2010. These species

251 occurrences were added to our list of taxa present in each treatment (Table 1), but were not used

252 for calculating relative abundances.

\section{Statistical analyses}

255 Data from all subsamples taken within an individual $90 \times 90 \mathrm{~m}$ treatment plot - i.e.,

256 individual depth strata within seed bank cores, individual vegetation subplots, or individual litter

257 baskets - were pooled (normally averaged; summed in the case of seed rain) to yield a single

258 value for each variable for each plot. This pooling avoids pseudoreplication and inflation of

259 degrees of freedom and probability of Type I statistical errors (Gotelli and Ellison 2012). Except

260 in the multivariate analysis described at the end of this section, seed rain data were pooled for the

261 five years (2005-2009).

262 To standardize data across regeneration inputs (Fig. 1), we calculated the relative

263 abundances of each species in the seed bank, seed rain, and herbaceous and sapling layers as the

264 sum of all occurrences within each input - percent covers, numbers of seeds, or numbers of

265 germinating recruits - divided by the total number of all occurrences. Because the majority of

266 species were very rare $(<1 \%$ relative abundance), relative abundances were computed only for

267 the 14 most frequent genera observed in the combination of seed bank, seed rain, and field plots

268 (Acer, Betula, Pinus, Prunus, Quercus, Tsuga, Mitchella, Rubus, Viburnum, Aralia, Lysimachia, 
Maianthemum, Carex, and Juncus; see Results). Although monilophytes and lycophytes

270 comprised a significant portion of the regenerating flora, they were largely undetected in the seed

271 bank (except for one species, Dennstaedtia puncilobula, that could not be ruled out as a weedy

272 greenhouse recruit), and thus were excluded from the analysis. When multiple species were

273 recorded in a given genus (i.e., Betula, Rubus, Carex, Juncus, Aralia, and Viburnum), species

274 were summed within that genus because they were very similar in physiognomy, successional

275 status, and shade-tolerance (with a possible exception of Aralia hispida and A. nudicaulis).

276 Initial analyses of block and treatment effects on germination were done using linear

277 mixed models, in which block was considered a random effect and treatment a fixed effect; F-

278 ratios for treatment effects were adjusted for the block term (Gotelli and Ellison 2012: 304).

279 Comparisons of total numbers of seeds germinating in the three treatments were done using a

280 Chi-square test. Kolmogorov-Smirnov tests were used to compare shapes of relative abundance

281 distributions among the three canopy-manipulation treatments. Kendall's coefficient of

282 concordance was used to determine whether the rank-abundance distributions of species in the

283 seed rain differed among the three canopy-manipulation treatments. Pair-wise Chao-Sørensen

284 abundance-based similarities (Chao et al. 2006) were computed among all possible pairings of

285 species compositions of the seed bank, seed rain, herbs, and saplings. The two abundances of

286 any pairwise comparison were considered significantly dissimilar if the bootstrapped $95 \%$

287 confidence interval on the similarity index did not include 1.0.

288 In addition to exploring and analyzing the responses of individual species, we assessed

289 community-level responses using ordination and permutational multivariate analysis of variance

290 (PERMANOVA; Anderson 2001). We first computed a Bray-Curtis dissimilarity matrix from

291 the data consisting of the relative abundance of the 14 most abundant genera in the seed bank, 
292 seed rain, herbaceous layer, and saplings from each treatment plot. We then modeled changes in

293 the dissimilarity as a function of regeneration component and canopy treatment (both of which

294 entered as fixed factors) and the continuous covariate was the time since treatment. The block

295 effect entered the PERMANOVA model as a "stratum" that constrained the permutations.

296 Significance tests were based on F-tests from sequential sums-of-squares from 1,000

297 permutations of the raw data.

298 Linear modeling was done with the lme function in the nlme library of the R statistical

299 software, version 2.12.2 (R Development Core Team 2007). Chi-square tests were done with the

300 chisq.test function in R's stats library, Kolmogorov-Smirnov tests that adjust for ties were done

301 using the ks.boot function in R's Matching library, and concordance of ranked abundances of

302 seed rain data among treatments was computed with the kendall function in R's irr library.

303 Computations of Chao-Sørensen similarities and bootstrapped confidence intervals were done

304 using EstimateS version 8.20 (Colwell 2006). Ordinations and PERMANOVA were done,

305 respectively, using the cca and adonis functions in R's vegan library. For clarity of presentation,

306 only means of the two replicate plots of each treatment are plotted for 2004 and 2010 seed-bank

307 and forest vegetation data and for the seed-rain data; within-treatment standard deviations are

308 included only for time series of herbaceous layer relative abundances. All raw data are available

309 from the Harvard Forest Data Archive (http://harvardforest.fas.harvard.edu/data/archive.html),

310 datasets HF-105 (seed-bank and seed-rain data), HF-106 (vegetation including herbs, shrubs, and

311 trees), and HF-126 (canopy tree data).

312

\section{Results}

\section{Composition of the seed rain}


Seed rain composition from 2005-2009 was similar among all three treatments (compare

316 graphs at the top of Figs. 2-4; inset of Fig. 5). Although rank abundances shifted among a few of

317 the rarer species among the treatments (Kendall's $W=0.848$, d.f. $=5, p=0.026$ ), there were no

318 significant pair-wise differences in the shapes of the relative abundance distributions between

319 treatments (2-sample Kolmogorov-Smirnov test: hemlock control vs. girdled, $D=0.17, p=1$;

320 hemlock control versus logged, $D=0.33, p=0.93$; girdled vs. logged, $D=0.33, p=0.93$ ), and

321 Chao-Sørenson indices ranged from $0.99-1.00$. The seed rain consisted primarily of Betula

322 species (particularly $B$. lenta, relative abundance range $0.71-0.91$ ), with much smaller

323 proportions (0.04-0.09) of T. canadensis (top graphs in Figs. 2 - 4; inset of Fig. 5). Pinus

324 strobus, Q. rubra, and A. rubrum also appeared in multiple seed rain samples, but at very low

325 relative abundances: $0.02-0.06,0.002-0.01$, and $0.01-0.03$ respectively. Spikes in seed

326 production by B. lenta, reflected in absolute increases in seeds per quarter, occurred in 2006 and

327 2009, coinciding with more modest spikes in the same years by T. canadensis (data not shown).

328 The other, much rarer taxa found in the seed rain were: Swida alternifolia (L.f.) Small, Fraxinus

329 americana L., Nyssa sylvatica Marsh., Ostrya virginiana (P.Mill.) K. Koch, Polygonatum

330 biflorum (Walter) Elliott, Rhus hirta (L.) Sudworth, Carex sp., and Vaccinium sp.

331 Considering the common canopy tree species in our top 14 taxa, the similarity of the

332 relative abundances of canopy species (2006-2009) to the relative abundances of species in the

333 seed rain over the same period ranged from $0.998-1$, so the relative abundance of seeds in the

334 seed rain could be considered to be a reasonable proxy for the composition of species in the

335 canopy (see also Table 1). Quercus alba and Q. bicolor were rare members of the canopy that

336 were not found in the seed rain, seed bank, or forest-floor vegetation. Fraxinus americana, 
337 Nyssa sylvatica, and Ostrya virginiana were present in the seed rain (Table 1), but N. sylvatica

338 was never found in any of the treatment plots.

\section{Composition of the seed bank}

Thirty-seven taxa germinated in the seed trays during 2010, of which two immature

342 plants (Gaultheria cf. hispidula (L.) Muhl. ex Bigelow and Carex cf. ovales) could only be

343 identified definitively to genus (Fig. 6). Although the total species richness of the seed bank in

3442010 (37 taxa) was greater than the 30 taxa recorded in 2004, the average per-treatment species

345 richness (24 in the hemlock controls, 21 in the girdled treatment; and 23 in the logged treatment)

346 was nearly identical to those estimated by rarefaction for the pre-treatment control plots (24

347 species) in 2004. Species richness of germinants did not differ significantly among the three

348 treatments in $2010\left(\chi^{2}=0.2\right.$, d.f. $\left.=2, p=0.9\right)$.

A total of 529 seedlings emerged in the seed-bank trays in 2010; a linear mixed-effects

350 model on log-transformed total germinants $(+1)$ yielded a significant effect of block $(F=5.01$,

351 d.f. $=1,56, p=0.03)$ but no effect of treatment $(\mathrm{F}=2.01$, d.f. $=2,56, p=0.14)$. Germination

352 totals were similar between 2010 and $2004\left(\chi^{2}=6.0\right.$, d.f. $\left.=2, p=0.19\right)$, with 195 seedlings in the

353 girdled treatment (vs. 162 in 2004), 143 in logged treatment (vs. 147), and 191 in the hemlock

354 control treatment (vs. 138). For the most common 14 genera identified among all of the

355 regeneration input groups, the rank-abundance distributions did not differ significantly between

3562004 and 2010 in any of the treatments (hemlock controls, $D=0.21, p=0.69$; girdled treatment,

$357 D=0.21, p=0.58$; logged treatment, $D=0.21, p=0.68$ ). When we compared the composition

358 of the seed bank in 2004 to the composition of the seed bank in 2010 in the control and each of 
the two canopy manipulation treatments, the seed banks of 2004 and 2010 were most similar in

360 the hemlock control and least similar in the logged treatment (Table 2).

Seventeen species were observed in the seed bank in both 2004 and 2010. Of these, 13

362 were comparatively common and abundant throughout all the samples (Fig. 6). Nine "new"

363 species appeared in the 2010 control samples, 8 in the samples from girdled treatment, and 14 in

364 samples from the logged treatment (Table 1). These recent arrivals in the seed bank were

365 infrequent germinants that were also rarely documented from the standing vegetation, with the

366 exceptions of Phytolacca americana (detected in one of the two girdled plots), Rubus

367 occidentialis (in all treatments), and Viburnum nudum var. cassinoides (in the logged and control

368 treatments).

369 To test our hypothesis that shallow seed bank layers would contribute more substantially

370 to standing vegetation than the deeper layers, we next compared the numbers and types of

371 germinants emerging from the upper 0-10 $\mathrm{cm}$ strata (roughly corresponding to the $\mathrm{O}+\mathrm{A}$

372 horizons) of each core with those emerging in the lower, 10-20 cm deep stratum (roughly

373 corresponding to the B horizon; Fig. 6). The majority (57\%) of the dominant taxa were present

374 in both strata, including B. lenta, Rubus spp., Lysimachia quadrifolia L., Carex pensylvanica

375 Lam., and Juncus tenuis Willd. However, several other forb and graminoid taxa emerged only

376 from the 10-20 cm layer (Fig. 6), likely reflecting the agricultural past of these \pm 70 -year-old

377 hemlock stands (Kernan 1980; Bettmann-Kerson 2007). Similar species had germinated from

378 the seed bank in 2004 (Sullivan and Ellison 2006); however, none of these taxa was observed in

379 the standing vegetation of the treatment plots between 2004 and 2010 (Table 1). We also

380 detected no significant differences in the rank-abundance distributions of the most common 14

381 genera between the upper and lower strata (hemlock control, $D=0.21, p=0.69$; girdled 
382 treatment, $D=0.14, p=0.94$; logged treatment, $D=0.14, p=0.91$ ), and Chao-Sørenson

383 similarities ranged from $0.652( \pm 0.300$, S.D. $)$ to $0.965( \pm 0.057)$, so we concluded that the upper

384 horizons captured the most important species also found in the lower layer. We thus used data

385 on species composition from the upper stratum in subsequent analyses of relative abundance.

386 Examining the rank abundances of the top 14 genera germinating from the upper horizons, we

387 found no significant differences in the rank-abundance distribution between 2004 and 2010

388 (hemlock controls, $D=0.43 ; p=0.42$; girdled treatment, $D=0.50, p=0.36$; logged treatment, $D$

$389=0.38, p=0.48)$. As with the full taxon pool, a linear mixed-effects model yielded a significant

390 effect of block $(\mathrm{F}=7.6$, d.f. $=1,56, p=0.008)$ but no effect of treatment $(\mathrm{F}=2.8$, d.f $=2,56, p$

$391=0.064)$ on total germinants in the upper layer.

392

393 Composition of the standing vegetation

394 The hemlock control treatment contained the fewest overall numbers of forest-floor

395 species (21 recorded over the six-year period), approximately half the species found in the

396 girdled treatment (50) and the logged treatment (42) (Table 1). The three treatments did,

397 however, share some species, including Acer rubrum seedlings, Mitchella repens, Betula

398 papyrifera, Quercus rubra, Lysimachia borealis, Monotropa uniflora, and several monilophyte

399 species (Table 1). The girdled treatment was most similar in species composition to the logged

400 treatment (Chao-Sørenson Index of similarity on species presence-absence $S=0.696$ ), and least

401 similar to the hemlock control treatment $(S=0.413)$; the logged and control treatments shared

402 just under half of the species present $(S=0.438)$.

403

404 Changes in vegetation composition from 2004 to 2010 
Star plots and time-series graphs of the relative abundances of the 14 common taxa in the

406 seed bank, seed rain, herbaceous layer, and sapling cohort illustrate the shifts in forest

407 composition occurring in the control and two canopy manipulation treatments (Figs. 2 - 4).

408 In the intact hemlock stands (Fig. 3), the forest-floor vegetation remained stable through

409 time, and was very similar in 2004 and 2010 (Table 2). Acer rubrum predominated, along with

410 slightly increasing proportions of $P$. strobus and occasional seedlings of $T$. canadensis and $Q$.

411 rubra. A few T. canadensis saplings were observed in 2004 and 2010; no other species were

412 present as saplings (Fig. 3). The vegetation in the control hemlock treatment in 2010 reflected a

413 moderate influence of the seed rain (similarity $=0.43$; Table 2), which contained $T$. canadensis

414 seeds (produced by the canopy), as well as P. strobus, A. rubrum, and Q. rubra. Although a

415 large proportion of wind-dispersed Betula seeds were present in the seed rain (Fig. 2), the

416 majority joined the seed bank but did not emerge as seedlings in the heavily shaded understory.

417 The seed bank showed little similarity with the understory vegetation (similarity =0.07; Fig. 2,

418 Table 2); light-demanding genera such as Carex and Rubus, though present in the seed bank,

419 never appeared under the dense T. canadensis canopy in the control treatment.

420 In the girdling treatment, the pre-treatment 2004 understory was composed of $T$.

421 canadensis seedlings, $P$. strobus, a lesser proportion of $A$. rubrum, and a small amount of $Q$.

422 rubra and Mitchella repens L. (Fig. 3). A few Betula saplings were also present in 2004 (Fig. 3);

423 the 49 T. canadensis saplings initially present in the two treatment plots were killed by girdling.

424 Although the composition of the seed rain recorded in the girdling treatment was very similar to

425 that of the hemlock control (compare Figs. 2 and 3), the proportion of T. canadensis seed

426 declined as the canopy trees gradually died. As in the hemlock control, the seed bank in the

427 girdled treatment bore little resemblance to the forest-floor vegetation in 2004 (Fig. 3), and also 
428 reflected minimal influence of the seed rain, except for the preponderance of Betula. By 2010,

429 however, the seed bank may have contributed to the emergence of a small proportion of Rubus

430 species, and was much more similar to the forest-floor composition overall (similarity $=0.75$;

431 Table 2, Fig. 3). As the canopy gradually opened, B. lenta seedlings became more prominent in

432 the regenerating vegetation as they germinated from the seed bank, joining P. strobus, A.

433 rubrum, and T. canadensis seedlings produced by the dying canopy trees. Betula lenta

434 comprised the majority of the sapling layer, with a small proportion of Prunus spp. recruiting 435 (Fig. 3).

436 The logged treatment showed a dramatic increase in vegetation between 2004 and 2010, 437 reflecting the sudden and nearly complete opening of the canopy (Fig. 4). Recruitment of new 438 species commenced in 2006 , one year after the two plots in this treatment had been logged, and 439 accelerated in 2007. Before logging, the understory had comprised the same species as the other 440 two treatment types, dominated by $T$. canadensis, with lesser proportions of $P$. strobus, $A$.

441 rubrum, and Q. rubra. Seed rain over time, disproportionately dominated by Betula, was similar 442 to that observed in the hemlock and girdled treatments, with the exception of a small amount of 443 Carex spp. seed arriving in 2007, possibly transported by birds or wind. By 2010, the forest444 floor vegetation bore little resemblance to its former 2004 composition (similarity $=0.20$; Table 445 2, Fig. 4). The relative abundance distribution of the seed bank became increasingly even from 4462004 to 2010, and more similar to the regenerating vegetation, as Rubus, Carex, Aralia, and 447 Lysimachia became more prevalent over time (Fig. 4). Although Prunus serotina Ehrh. var. 448 serotina and T. canadensis were the only sapling species found in the logged treatment in 2004 449 (Fig. 4), and these persisted after logging, they were quickly joined by an influx of B. lenta 450 saplings and some A. rubrum. Thus, the 2010 sapling layer was highly dissimilar to the 2004 
451 sapling profile (similarity $=0.03$; Table 2, Fig. 4). Overall, recruitment of new species,

452 especially forbs and graminoids, took place much more rapidly in the logged treatment than in

453 the girdled treatment.

454

455 Multivariate analyses

456 Canonical correspondence analysis (Fig. 5) revealed similar patterns to those observed in

457 Figs. 2 - 4. After 6 years, the seed bank of the girdled and logged treatments showed increased

458 dominance of graminoids and forbs, but was essentially unchanged in the hemlock control

459 treatment. Similarly, vegetation trajectories in girdled and logged treatments moved towards

460 assemblages dominated by forbs, herbs, and early-successional trees. The understory vegetation

461 in the control treatment was similar in 2004 and 2010, but in the intervening years had moved

462 around ordination space because of year-to-year variability in seedling recruitment and mortality.

463 The first two axes of the ordination accounted for $43 \%$ of the variance in the data. Permutational

464 multivariate analysis of variance (with permutations constrained by blocks) of these data

465 identified significant differences through time $(p=0.001)$ among regeneration inputs $(p=$

$4660.001)$, canopy manipulation treatment $(p=0.001)$, and the regeneration input $\times$ canopy

467 treatment interaction $(p=0.001)($ Table 3$)$.

469 Discussion

470 We have demonstrated here an approach that can be used to create a conceptual model

471 (Fig. 1) of the responses of a widespread temperate forest type to disturbances such as defoliation

472 irrupting insects, pathogens, or salvage logging. We have shown that reorganization of the herb,

473 shrub, and sapling layers has taken place more slowly in the girdled treatment, exhibiting the 
474 gradual die-back typical of adelgid-infested stands, than in the logged treatment, where

475 conditions changed abruptly. Our findings parallel those of other long-term studies of declining

476 hemlock stands (Small et al. 2005; Eschtruth et al. 2006; Spaulding and Rieske 2010), and

477 accord with Kizlinski et al. (2002) and Orwig et al. (2008), who found that logging resulted in

478 faster and denser colonization by B. lenta than gradual mortality of the overstory due to the

479 adelgid. Observations from the girdled treatment will continue to provide predictions of the

480 responses of intact hemlock stands as the adelgid begins to infest them in coming years (Yorks et

481 al. 2003; Ellison et al. 2010).

482 Before the onset of treatments in 2005, all hemlock plots, regardless of block, were very

483 similar in species composition (Fig. 5). The canopy and understory both were dominated by $T$.

484 canadensis and most other understory species were absent or suppressed. Following treatments,

485 we asked if and how the current vegetation differed between logged and girdled stands. By

486 2010, plots in the girdled and logged treatments were broadly similar in species composition, but

487 differed in two important respects. First, because all seedlings, saplings, and mature hemlocks

488 were girdled, they slowly declined and by 2010, they comprised a negligible part of the

489 vegetation in the girdled treatment. Plots in the logged treatment gained a small number of $T$.

490 canadensis recruits, possibly contributed by seed rain from unharvested $(<20 \mathrm{~cm}$ diameter $)$ but

491 reproductive trees or from trees just outside the treatment plots. Second, the abundance and

492 species richness of forbs and graminoids increased in the logged treatment quite rapidly,

493 beginning in earnest in 2007 (Figs. 4, 5). In contrast, the slowly declining canopy of hemlocks

494 in the girdled treatment suppressed recruitment of forbs and graminoids; even shrub recruitment

495 was comparatively low, but was accelerating as of 2010 (Figs. 3, 5). 
Next, we explored whether the initial compositions of the seed bank, seed rain, canopy,

497 and forest-floor vegetation were similar within and among treatments, and observed whether the composition of these regeneration components diverged through time or among treatments. The seed bank composition in 2004 was dominated strongly by Betula spp., and bore little similarity to the standing vegetation composition. The composition and richness of the 2010 seed bank remained similar to the 2004 bank (Table 2), with some turnover in rare species and singletons (species represented by only a single seedling). The 2010 seed bank continued to differ in composition from the understory in the hemlock control treatment (Figs. 2, 5). Studies comparing the composition of the seed bank and standing vegetation in intact forests usually find little correspondence, with Sørenson similarities typically < 0.6 (reviewed by Hopfensperger 2007), and our data from our hemlock control treatment are no exception (Table 2, Figs. 2, 5). Such disparities have been noted in previous studies of dense-canopy conifer forests dominated by T. canadensis (Catovsky and Bazzaz 2000) or other species (e.g., Berger et al. 2004; Eycott et al. 2006).

In the logged and girdled treatments, however, the composition of the standing vegetation became more similar over time to the seed banks of 2004 (Table 2) and 2010 (Figs. 3, 4) as more species were able to establish under the open canopy. As disturbances create new opportunities for recruitment from the persistent seed bank, and the changing vegetation contributes increasingly to the seed bank in turn, similarities between the seed bank and the forest-floor vegetation increase, as we observed in the girdled and logged treatments (Figs. 3 ,4). The preponderance of $B$. lenta seeds, plus the relative rarity of other taxa, led to higher similarity in the seed banks of all treatments between 2004 and 2010 (Table 2) than inspection of the relative abundance plots might suggest (Figs. 3, 4). Nevertheless, the dissimilarity between 2004 
519 and 2010 in the seed banks of the logged treatment was greater than in either the control or

520 girdled treatments (Table 2). This finding was consonant with our predictions, and leads to the

521 further prediction that the future seed bank will continue to diverge in composition from the pre-

522 treatment seed bank. In the long term, the seed bank composition of the girdled treatment should

523 eventually come to resemble that of the logged treatment. Likewise, the more speciose standing

524 vegetation in these two treatments will comprise a greater diversity of life forms than in intact

525 hemlock stands as forbs, shrubs, and graminoids become more important. We also predicted,

526 and observed, that the upper layers of the seed bank (0-10 $\mathrm{cm}$ depth) contributed more

527 germinants and showed higher similarity to the regenerating vegetation than the lower depths.

528 A closed hemlock canopy suppresses regeneration from seed rain, whereas newly opened

529 forests are conducive to regeneration from seed rain, especially if a few canopy trees or maturing

530 saplings remain. We predicted, and observed, that similarity between the seed rain and the

531 standing vegetation would increase as the canopy became a less important ecological filter, with

532 the seed rain more strongly influencing the vegetation when a partial canopy remains and woody

533 debris accumulates slowly (as in the girdled treatment). Overall, seed rain remained the

534 predominant factor contributing to regeneration in the girdled treatment, whereas both the seed

535 rain and seed bank contributed recruits in the logged treatment. As the last girdled or adelgid-

536 attacked hemlocks die, it will become more important to understand the composition of both

537 seed rain and seed banks to make predictions about future forest composition. Likewise, we

538 need to better understand the sources of recruiting monilophytes that can become very common

539 in newly opened stands (Yorks et al. 2003); propagules of these species were generally

540 undetected in the seed rain or seed bank. 
Because we used consistent methods to measure the compositions of the seed bank, seed

542 rain, and standing vegetation among years, our data on these different inputs could be tracked

543 and compared through time to inform a general model of forest regeneration (Fig. 1). We

544 caution that integrated studies such as this one are challenging to undertake and to interpret. The

545 timing and frequency of monitoring of different vegetation pools in the Harvard Forest Hemlock

546 Removal Experiment differed somewhat; for example, seed-rain monitoring did not commence

547 until after treatments were imposed, whereas before-and-after data were available for both the

548 seed bank and the standing vegetation. Standing vegetation was censused annually, but seed

549 bank composition was assessed at a six-year interval - insufficiently frequent to permit

550 development of a path analysis linking inputs and outputs (cf. Caballero et al. 2008). Finally,

551 sampling took place at different spatial scales within treatment plots, from randomly-located

552 small soil cores for seed banks and litter baskets for seed rain, to transects of $1 \times 1 \mathrm{~m}$ subplots for

553 seedlings and herbaceous vegetation and larger $30 \times 30-\mathrm{m}$ subplots for sapling counts. However,

554 these sampling methods were appropriate for yielding accurate estimates of relative abundances

555 and species composition of each vegetation component. Ideally, integrated long-term studies

556 should be tightly coordinated in time and space to permit more rigorous quantitative comparisons

557 and development of path models. Such coordination also will allow for species responses to be

558 more mechanistically related to broader ecosystem responses (Yorks et al. 2003).

\section{Acknowledgements}

561 The Harvard Forest Hemlock Removal Experiment is a core project of the Harvard Forest Long

562 Term Ecological Research (LTER) site supported by the U.S. National Science Foundation

563 (award number 06-20443). We thank Samantha Marshall, Chelsea Carr, and Mack Bennett for 
564 sorting seeds from litterfall samples. David Foster, David Orwig, two anonymous reviewers, and

565 the associate editor contributed comments that greatly improved the manuscript.

566

567 References

568 Anderson, M.J. 2001. A new method for non-parametric multivariate analysis of variance.

$569 \quad$ Austral Ecology 26(1): 32-46.

570 Bettmann-Kerson, P. 2007. Hemlock removal experiment - dendrochronological record. Harvard Forest Data Archive HF-086. Available from http://harvardforest.fas.harvard.edu:8080/exist/xquery/data.xq?id=hf086 [accessed 29

574 Berger, T.W., Sun, B., and Glatzell, G. 2004. Soil seed banks of pure spruce (Picea abies) and 575 adjacent mixed species stands. Plant and Soil 264(1-2): 53-67.

576 Burton, J.I., Mladenoff, D.J., Clayton, M.K., and Forrester, J.A. 2011. The roles of 577 environmental filtering and colonization in the fine-scale spatial patterning of groundlayer plant communities in north temperate deciduous forests. J. Ecol. 99(3): 764-776.

579 Caballero, I., Olano J.M., Loidi, J., and Escudero, A. 2008. A model for small-scale seed bank and standing vegetation along time. Oikos 117(12): 1788-1795.

581 Catovsky, S., and Bazzaz, F.A. 2000. The role of resource interactions and seedling regeneration 582 in maintaining a positive feedback in hemlock stands. J. Ecol. 88(1): 100-112.

583 Catovsky, S., and Bazzaz, F.A. 2002. Feedbacks between canopy composition and seedling 584 regeneration in mixed conifer broad-leaved forests. Oikos 98(2): 403-420. 
585

586

587

588

589

590

591

592

593

594

595

596

597

598

599

600

601

602

603

604

605

606

Chao, A., Chazdon, R.L., Colwell, R.K., and Shen, T.-J. 2006. Abundance-based similarity indices and their estimation when there are unseen species in samples. Biometrics 62(2): $361-371$.

Colwe11, R. K. 2006. EstimateS: Statistical estimation of species richness and shared species from samples. Version 8. Available from http://purl.oclc.org/estimates [accessed 30 December 2011].

D’Amato, A.W., Orwig, D.A., and Foster, D.R. 2008. Understory vegetation in old-growth and second-growth Tsuga canadensis forests in western Massachusetts. Forest Ecol. Managem. 257(3): 1043-1052.

Drake, D.R. 1998. Relationships among the seed rain, seed bank and vegetation of a Hawaiian forest. J. Vegetation Sci. 9(1): 103-112.

Decocq, G., Valentin, B., Toussaint, B., Hendoux, F., Saguez, R., and Bardat, J. 2004. Soil seed bank composition and diversity in a managed temperate deciduous forest. Biodiversity and Conservation 13(13): 2485-2509.

Ellison, A.M., Bank, M.S., Clinton, B.D., Colburn, E.A., Elliott, K., Ford, C.R., Foster, D.R., Kloeppel, B.D., Lovett, G.M., Mohan, J., Orwig, D.A., Rodenhouse, N.L., Sobczek, W.V., Stinson, K.A., Stone, J.K., Swan, C.M., Thompson, J., Von Holle, B., and Webster, J.R. 2005. Loss of foundation species: consequences for the structure and dynamics of forested ecosystems. Front. Ecol. Environ. 3(9): 479-486.

Ellison, A.M., Barker-Plotkin, A.A., Foter, D.R., and Orwig, D.A. 2010. Experimentally testing the role of foundation species in forests: the Harvard Forest Hemlock Removal Experiment. Methods Ecol. Evol. 1(2): 168-179. 
607 Eschtruth, A.K., Cleavitt, N.L., Battles, J.J., Evans, R.A., Fahey, T.J., 2006. Vegetation

608 dynamics in declining eastern hemlock stands: 9 years of forest response to hemlock

609 woolly adelgid infestation. Canad. J. Forest Res. 36(6): 1435-1450.

610 Eycott, A.E., Watkinson, A.R., and Dolman, P.M. 2006. The soil seed bank of a lowland conifer

611 forest: The impacts of clear-fell management and implications for heathland restoration.

$612 \quad$ Forest Ecol. Managem. 237(1-3): 280-289.

613 Foster, D.R., and Orwig, D.A. 2006. Preemptive and salvage harvesting of New England forests:

614 when doing nothing is a viable alternative. Conservation Biol. 20(4): 959-970.

615 Foster, D.R., Oswald, W.W., Faison, E.K., Doughty, E.D., and Hansen, B.C.S. 2006. A climatic

616 driver for abrupt mid-Holocene vegetation dynamics and the hemlock decline in New

$617 \quad$ England. Ecology 87(12): 2959-2966.

618 Gotelli, N.J. and Ellison, A.M. 2012. A primer of ecological statistics, $2^{\text {nd }}$ edition. Sinauer 619 Associates, Sunderland, MA.

620 Graae, B.J. and Sunde, P.B. 2000. The impact of forest continuity and management on forest 621 floor vegetation evaluated by species traits. Ecography 23(6): 720-731.

622 Greene, D.F and Johnson, E.A. 1994. Estimating the mean annual seed production of trees. $623 \quad$ Ecology 75(3): 642-647.

624 Haines, A. 2011. Flora Novae Angliae: A manual for the identification of native and naturalized 625 higher vascular plants of New England. Yale University Press, New Haven, CT.

626 Hopfensperger, K.N. 2007. A review of similarity between seed bank and standing vegetation 627 across ecosystems. Oikos 116(9): 1438-1448.

628 Jenkins, J., Motzkin, G., and Ward, K. 2008. The Harvard Forest Flora. Harvard Forest Paper 629 No. 28, Petersham, MA. 
630 Kernan, B. 1980. Simes Tract, 1980 Report. Simes Lot, 1971-2006, Folders 1-6. Stand Records for Harvard Forest Simes Lot, Harvard Forest, Petersham, MA. Available from http://nrs.harvard.edu/urn-3:FCOR.FORST:1115608?n=377 [accessed 5 June 2011].

633 Kizlinski, M.L., Orwig, D.A., Cobb, R.C., and Foster, D.R. 2002. Direct and indirect ecosystem consequences of an invasive pest on forests dominated by eastern hemlock. J. Biogeography 29(10-11): 1489-1503.

Krasny, M.E., and Whitmore, M.C. 1992. Gradual and sudden forest canopy gaps in Allegheny northern hardwood forests. Can. J. For. Res. 22(2): 139-143.

638 Lovett, G.M., Canham, C.D., Arthur, M.A., Weathers, K.C., and Fitzhugh, R.D. 2006. Forest ecosystem responses to exotic pests and pathogens in Eastern North America. Bioscience

Lustenhouwer, N., L. Nicoll, and A. M. Ellison. 2012. Microclimatic effects of the loss of a

643 Montgomery, F.H. 1977. Seeds and fruits of plants of eastern Canada and northeastern United States. University of Toronto Press, Toronto, Canada.

645 Myers, J.A., and Harms, K.E. 2011. Seed arrival and ecological filters interact to assemble highdiversity plant communities. Ecology 92(3): 676-686.

647 Orwig, D.A. and Foster, D.R. 1998. Forest response to the introduced hemlock woolly adelgid in southern New England, USA. J. Torrey Bot. Soc. 125(1): 60-73.

649 Orwig, D.A., Foster, D.R., and Mausel, D.L. 2002. Landscape patterns of hemlock decline in 650 New England due to the introduced hemlock woolly adelgid. Journal of Biogeography 29(10-11): 1475-1487. 
652 Orwig, D.A., Cobb, R.C., D’Amato, A.W., Kizlinski, M.L., and Foster, D.R. 2008. Multi-year ecosystem response to hemlock woolly adelgid infestation in southern New England forests. Canad. J. Forest Res. 38(4): 834-843

Orwig, D.A., Barker Plotkin, A.A., Davidson, E.A., Foster, D.R., Lux, H., Savage, K.E., and Ellison, A.M. in review. Foundation species loss affects vegetation structure more than ecosystem function in a northeastern USA forest. Submitted to Journal of Ecology.

Paradis, A., Elkinton, J., Hayhoe, K, and Buonaccorsi, J. 2008. Role of winter temperature and climate change on the survival and future range expansion of the hemlock woolly adelgid

Price, J.N., Wright, B.R., Gross, C.L., and Whalley, W.R.D.B. 2010. Comparison of seedling (Adelges tsugae) in eastern North America. Mitigation and Adaptation Strategies for

emergence and seed extraction techniques for estimating the composition of soil seed

Global Change 13(5-6): 541-554. banks. Methods Ecol. Evol. 1(2): 151-157.

R Development Core Team. 2007. R: A language and environment for statistical computing. R Foundation for Statistical Computing, Vienna, Austria. http://www.R-project.org/.

Sackett, T. E., S. Record, S. Bewick, B. Baiser, N. J. Sanders, and A. M. Ellison. 2011. Response of macroarthropod assemblages to the loss of hemlock (Tsuga canadensis), a foundation species. Ecosphere 2: art74.

Small, M.J., Small, C.J., and Dreyer, G.D. 2005. Changes in a hemlock-dominated forest following woolly adelgid infestation in southern New England. J. Torrey Bot. Soc 132(3): 458-470.

Smith, D. M. 1986. The practice of silviculture, eighth edition. John Wiley \& Sons, New York, 674 USA. 
675 Spaulding, H.L, and Rieske, L.K. 2010. The aftermath of an invasion: Structure and composition 676 of Central Appalachian hemlock forests following establishment of the hemlock woolly 677 adelgid, Adelges tsugae. Biol. Invasions 12(9):3135-3143.

678 Sullivan, K.A., and Ellison, A.M. 2006. The seed bank of hemlock forests: implications for 679 forest regeneration following hemlock decline. J. Torrey Bot. Soc. 133(3): 393-402.

680 United States Department of Agriculture (USDA) (n.d.) Official soil series descriptions. Soil 681 Survey Staff, Natural Resources Conservation Service, Lincoln, Nebraska. $682 \quad$ http://soils.usda.gov/technical/classification/osd/index.html.

683 Yorks, T.E., Leopold, D.J., and Raynal, D.J. 2000. Vascular plant propagule banks of six eastern 684 hemlock stands in the Catskill Mountains of New York. J. Torrey Bot. Soc. 127(1): 8768593.

686 Yorks, T.E., Leopold, D.J., and Raynal, D.J. 2003. Effects of Tsuga canadensis mortality on soil 687 water chemistry and understory vegetation: possible consequences of an invasive insect 688 herbivore. Can. J. For. Res. 33(8): 1525-1537. 
691 Table 1. Species found in the seed rain (R), seed bank (B), understory vegetation (V), and

692 canopy (C) samples (excluding intermediate and suppressed trees in the canopy) within each of

693 the three canopy manipulation treatments from 2005-2010. Asterisks indicate species that were

694 detected in the 2004 seed bank samples (Sullivan and Ellison 2006), but not in the 2010 seed

695 bank samples.

\begin{tabular}{|c|c|c|c|}
\hline \multirow[b]{2}{*}{ Species } & \multicolumn{3}{|c|}{ Canopy treatment } \\
\hline & $\begin{array}{c}\text { Hemlock } \\
\text { control }\end{array}$ & $\begin{array}{c}\text { Hemlocks } \\
\text { girdled }\end{array}$ & $\begin{array}{c}\text { Hemlocks } \\
\text { logged }\end{array}$ \\
\hline \multicolumn{4}{|l|}{ Trees (including seedlings, saplings, and canopy) } \\
\hline Acer rubrum $\mathrm{L}$. & $\mathrm{R}, \mathrm{V}, \mathrm{C}$ & $\mathrm{R}, \mathrm{V}, \mathrm{C}$ & $\mathrm{R}, \mathrm{V}, \mathrm{C}$ \\
\hline Betula alleghaniensis Britt.* & $\mathrm{C}$ & V & \\
\hline Betula lenta L. & $\mathrm{R}, \mathrm{B}, \mathrm{C}$ & $\mathrm{R}, \mathrm{B}, \mathrm{V}, \mathrm{C}$ & $\mathrm{R}, \mathrm{B}, \mathrm{V}, \mathrm{C}$ \\
\hline Betula papyrifera Marsh. & $\mathrm{B}, \mathrm{V}$ & B,V,C & V \\
\hline Carya sp. Nutt. & $\mathrm{V}, \mathrm{C}$ & V & $\mathrm{V}$ \\
\hline Fraxinus americana $\mathrm{L}$. & $\mathrm{R}, \mathrm{C}$ & & \\
\hline Fraxinus nigra Marsh. & & $\mathrm{C}$ & \\
\hline Nyssa sylvatica Marsh. & $\mathrm{R}$ & & \\
\hline Ostrya virginiana (P. Mill.) K. Koch & & & $\mathrm{R}$ \\
\hline Pinus strobus L. & $\mathrm{R}, \mathrm{V}, \mathrm{C}$ & $\mathrm{R}, \mathrm{V}, \mathrm{C}$ & $\mathrm{R}, \mathrm{B}, \mathrm{V}, \mathrm{C}$ \\
\hline Populus grandidentata Michx. & & & B \\
\hline Prunus pensylvanica L. f. var. pensylvanica & & $\mathrm{V}$ & V \\
\hline Prunus serotina Ehrh. var. serotina & $\mathrm{V}, \mathrm{C}$ & $\mathrm{V}$ & $\mathrm{V}$ \\
\hline Quercus alba L. & $\mathrm{C}$ & $\mathrm{V}, \mathrm{C}$ & $\mathrm{V}, \mathrm{C}$ \\
\hline Quercus bicolor Willd. & & $\mathrm{C}$ & \\
\hline Quercus rubra L. & $\mathrm{V}, \mathrm{C}$ & $\mathrm{V}, \mathrm{C}$ & $\mathrm{R}, \mathrm{V}, \mathrm{C}$ \\
\hline Quercus velutina Lam. & & & V \\
\hline Tsuga canadensis (L.) Carr. & $\mathrm{R}, \mathrm{B}, \mathrm{V}, \mathrm{C}$ & $\mathrm{R}, \mathrm{V}, \mathrm{C}$ & $\mathrm{R}, \mathrm{V}, \mathrm{C}$ \\
\hline \multicolumn{4}{|l|}{ Shrubs } \\
\hline Amelanchier sp. Medik. & & $\mathrm{V}$ & \\
\hline Berberis thunbergii DC. & & $\mathrm{V}$ & \\
\hline Celastrus orbiculatus Thunb. & & $\mathrm{V}$ & \\
\hline Comptonia peregrina (L.) Coult. & & B & $\mathrm{V}$ \\
\hline Corylus cornuta Marsh. ssp. cornuta & & $\mathrm{V}$ & \\
\hline Crataegus sp. L. & & $\mathrm{V}$ & $\mathrm{V}$ \\
\hline Diervilla lonicera P. Mill. & & & $\mathrm{V}$ \\
\hline Gaultheria cf. hispidula (L.) Muhl. ex Bigelow & & B & $\mathrm{B}$ \\
\hline Gaultheria procumbens L.* & & $\mathrm{V}$ & $\mathrm{V}$ \\
\hline
\end{tabular}




\begin{tabular}{|c|c|c|c|}
\hline \multirow[b]{2}{*}{ Species } & \multicolumn{3}{|c|}{ Canopy treatment } \\
\hline & $\begin{array}{l}\text { Hemlock } \\
\text { control }\end{array}$ & $\begin{array}{l}\text { Hemlocks } \\
\text { girdled }\end{array}$ & $\begin{array}{l}\text { Hemlocks } \\
\text { logged }\end{array}$ \\
\hline $\begin{array}{l}\text { Ilex mucronata (L.) M. Powell, Savol. \& S. } \\
\text { Andrews }\end{array}$ & & & $\mathrm{V}$ \\
\hline Ilex verticillata (L.) Gray & & V & V \\
\hline Mitchella repens L. & $\mathrm{V}$ & $\mathrm{V}$ & $\mathrm{B}, \mathrm{V}$ \\
\hline Myrica gale $\mathrm{L}$. & & & $\mathrm{V}$ \\
\hline Rhododendron periclymenoides (Michx.) Shinners & & V & \\
\hline Rhus copallinum L. var. latifolia Engl. & & $\mathrm{V}$ & $\mathrm{V}$ \\
\hline Rhus hirta (L.) Sudworth & $\mathrm{R}$ & & \\
\hline Rubus allegheniensis Porter & $\mathrm{B}$ & $\mathrm{V}$ & $\mathrm{B}, \mathrm{V}$ \\
\hline Rubus flagellaris Willd. & $\mathrm{B}$ & $\mathrm{B}, \mathrm{V}$ & $\mathrm{B}, \mathrm{V}$ \\
\hline Rubus hispidus L. & $\mathrm{B}$ & $\mathrm{B}, \mathrm{V}$ & $\mathrm{B}, \mathrm{V}$ \\
\hline Rubus idaeus L. ssp. ideaus & & $\mathrm{V}$ & $\mathrm{V}$ \\
\hline Rubus occidentalis L. & $\mathrm{B}$ & $\mathrm{B}, \mathrm{V}$ & $\mathrm{B}, \mathrm{V}$ \\
\hline Sambucus racemosa $\mathrm{L}$. & & $\mathrm{V}$ & $\mathrm{V}$ \\
\hline Sassafras albidum (Nutt.) Nees & & & $\mathrm{V}$ \\
\hline Sorbus americana Marsh. & & $\mathrm{V}$ & \\
\hline Swida alternifolia (L. f.) Small & $\mathrm{R}$ & $\mathrm{R}$ & \\
\hline Vaccinium angustifolium Ait.* & & $\mathrm{V}$ & $\mathrm{R}, \mathrm{V}$ \\
\hline Vaccinium corymbosum L. & & & $\mathrm{V}$ \\
\hline $\begin{array}{l}\text { Viburnum nudum L. var. cassinoides (Torr.) A. } \\
\text { Gray }\end{array}$ & $\mathrm{B}$ & $\mathrm{V}$ & $\mathrm{B}$ \\
\hline Vitis sp. L. & & V & $\mathrm{V}$ \\
\hline Forbs & & & \\
\hline Aralia hispida Vent. & & $\mathrm{V}$ & $\mathrm{B}, \mathrm{V}$ \\
\hline Aralia nudicaulis L. & V & & \\
\hline Chimaphila maculata (L.) Pursh & & V & \\
\hline Coptis trifolia (L.) Salisb. & & $\mathrm{V}$ & \\
\hline Epigaea repens $\mathrm{L}$. & & $\mathrm{V}$ & \\
\hline Erichtites hieraciifolius (L.) Raf. ex DC. (s.l.) & & $\mathrm{V}$ & $\mathrm{V}$ \\
\hline Eurybia cf. divaricata & $\mathrm{B}$ & $\mathrm{B}$ & $\mathrm{B}$ \\
\hline Euthamia graminifolia (L.) Nutt. & & & $\mathrm{B}$ \\
\hline Goodyera tesselata Lodd. & & $\mathrm{V}$ & \\
\hline Hypopitys monotropa Crantz & V & $\mathrm{V}$ & \\
\hline Lobelia inflata $\mathrm{L}$ & $\mathrm{B}$ & & \\
\hline Lysimachia borealis (Raf.) U Manns \& A. Anderb. & $\mathrm{V}$ & $\mathrm{V}$ & $\mathrm{V}$ \\
\hline Lysimachia quadrifolia $\mathrm{L}$ & & $\mathrm{B}, \mathrm{V}$ & $\mathrm{B}, \mathrm{V}$ \\
\hline Maianthemum canadense Desf. & $\mathrm{B}, \mathrm{V}$ & & \\
\hline Medeola virginiana $\mathrm{L}$. & $\mathrm{V}$ & $\mathrm{V}$ & \\
\hline Mollugo verticillata $\mathrm{L}$. & & $\mathrm{B}$ & $\mathrm{B}$ \\
\hline Monotropa uniflora $\mathrm{L}$. & $\mathrm{V}$ & $\mathrm{V}$ & $\mathrm{V}$ \\
\hline
\end{tabular}




\begin{tabular}{|c|c|c|c|}
\hline \multirow[b]{2}{*}{ Species } & \multicolumn{3}{|c|}{ Canopy treatment } \\
\hline & $\begin{array}{l}\text { Hemlock } \\
\text { control }\end{array}$ & $\begin{array}{l}\text { Hemlocks } \\
\text { girdled }\end{array}$ & $\begin{array}{c}\text { Hemlocks } \\
\text { logged }\end{array}$ \\
\hline Phytolacca americana L. var. americana & & $\mathrm{B}, \mathrm{V}$ & \\
\hline Polygonatum biflorum (Walter) Elliott & $\mathrm{R}$ & & \\
\hline Pyrola sp. L. & & $\mathrm{V}$ & \\
\hline Solidago sp. L. & & $\mathrm{V}$ & \\
\hline Taraxacum officinale G. H. Weber ex Wiggers & & & $\mathrm{B}$ \\
\hline Trifolium repens $\mathrm{L}$. & & & $\mathrm{B}$ \\
\hline Trillium erectum $\mathrm{L}$. & $\mathrm{V}$ & & \\
\hline Viola labradorica Schrank & $\mathrm{B}$ & & \\
\hline Viola sororia Willd. var. novae angliae Duchesne & $\mathrm{B}$ & $\mathrm{B}$ & $\mathrm{B}$ \\
\hline \multicolumn{4}{|l|}{ Graminoids } \\
\hline Agrostis hyemalis (Walt.) B. S. P. & $\mathrm{B}$ & & \\
\hline Brachyeletrum erectum (Schreb.) Beauv. & & & $\mathrm{V}$ \\
\hline Carex cf. ovales group & $\mathrm{B}$ & $\mathrm{B}$ & $\mathrm{R}, \mathrm{B}, \mathrm{V}$ \\
\hline Carex debilis Michx. var. rudgei Bailey & $\mathrm{B}$ & $\mathrm{B}$ & \\
\hline Carex deweyana Schweinitz & & $\mathrm{B}$ & \\
\hline Carex laxiflora $\mathrm{L}$. & $\mathrm{B}$ & & $\mathrm{B}$ \\
\hline Carex pensylvanica Lam. & $\mathrm{B}$ & $\mathrm{B}, \mathrm{V}$ & $\mathrm{B}, \mathrm{V}$ \\
\hline $\begin{array}{l}\text { Dichanthelium acuminatum (Sw. Gould) C. A. } \\
\text { Clark var. fasciculatum (Torr.) Freckmann }\end{array}$ & $\mathrm{B}$ & & B \\
\hline Dichanthelium clandestinum (L.) Gould & $\mathrm{B}$ & & \\
\hline Digitaria ischaemum (Schreb) Schreb ex Muhl. & $\mathrm{B}$ & $\mathrm{B}$ & $\mathrm{B}$ \\
\hline Juncus brevicaudatus (Engelm). Fern & $\mathrm{B}$ & & \\
\hline Juncus tenuis Willd & $\mathrm{B}$ & $\mathrm{B}$ & $\mathrm{B}$ \\
\hline Scirpus cyperinus (L.) Kunth & & $\mathrm{B}$ & \\
\hline \multicolumn{4}{|l|}{ Monilophytes and Lycophytes } \\
\hline Dendroycopodium obscurum (L.) A. Haines & $\mathrm{V}$ & $\mathrm{V}$ & $\mathrm{V}$ \\
\hline Dennstaedtia punctilobula (Michx.) T. Moore & $\mathrm{V}$ & $\mathrm{V}$ & $\mathrm{V}$ \\
\hline Dryopteris carthusiana (Vill.) H.P. Fuchs & $\mathrm{V}$ & $\mathrm{V}$ & $\mathrm{V}$ \\
\hline Dryopteris intermedia (Muhl. ex Willd.) Gray & & $\mathrm{V}$ & $\mathrm{V}$ \\
\hline Huperzia lucidula (Michx.) Trevisan & $\mathrm{V}$ & & \\
\hline Osmundastrum cinnamomeum (L.) C. Presl & $\mathrm{V}$ & $\mathrm{V}$ & \\
\hline Polypodium virginianum $\mathrm{L}$. & $\mathrm{V}$ & & \\
\hline Polystichum acrostichoides (Michx.) Schott & $\mathrm{V}$ & & \\
\hline
\end{tabular}


698 Table 2. Pair-wise similarities of seed bank composition (upper $10 \mathrm{~cm}$ stratum) in 2004 and

6992010 , forest-floor vegetation and saplings in 2004 and 2010, seed rain from 2005 to 2009. Seed

700 bank and understory vegetation data were averaged across samples within treatment plots, and

701 seed rain was summed across years within treatment plots so as to avoid pseudoreplication and

702 achieve an appropriate Type I statistical error rate (Gotelli and Ellison 2012). Values are Chao-

703 Sørensen abundance-based similarities (Chao et al. 2006) for the given pair. Values in bold are

704 significantly different from 1.00; pairs were significantly dissimilar at the $\alpha=0.05$ level based

705 on computation of bootstrapped $95 \%$ confidence intervals.

706

\begin{tabular}{|c|c|c|c|}
\hline \multicolumn{4}{|c|}{ Hemlock control treatment } \\
\hline & Seed bank 2010 & $\begin{array}{c}\text { Understory } \\
2010\end{array}$ & Saplings 2010 \\
\hline Seed rain 2005-2009 & 0.76 & 0.43 & 0.32 \\
\hline Seed bank 2004 & 0.94 & 0.07 & 0.00 \\
\hline Understory 2004 & 0.42 & 1.00 & 0.14 \\
\hline Saplings 2004 & 0.13 & 0.24 & 0.97 \\
\hline
\end{tabular}

\section{Girdled treatment}

$\begin{array}{ccc}\text { Seed bank 2010 } & \begin{array}{c}\text { Understory } \\ 2010\end{array} & \text { Saplings 2010 } \\ & \end{array}$

Seed rain 2005-2009

0.46

0.93

0.91

Seed bank 2004

0.93

0.75

0.59

Understory 2004

0.08

0.78

0.00

Saplings 2004

0.07

0.88

0.07

\section{Logged treatment}

$\begin{array}{ccc}\text { Seed bank 2010 } & \begin{array}{c}\text { Understory } \\ 2010\end{array} & \text { Saplings 2010 } \\ & \end{array}$

Seed rain 2005-2009

0.77

0.63

0.98

Seed bank 2004

0.86

0.67

0.87

Understory 2004

0.05

0.20

0.25

Saplings 2004

0.00

0.06

0.03 
709 Table 3. Summary table of the results of the permutational multivariate analysis of variance

710 (PERMANOVA) with permutations constrained by block. This analysis models community-

711 level responses (as a Bray-Curtis dissimilarity matrix) of the 14 most abundant genera in the seed

712 bank, seed rain, herbaceous layer, and saplings in each treatment. Regeneration component is

713 one of seed bank, seed rain, understory, or saplings; canopy manipulation is one of girdled,

714 logged, or hemlock control; year is one of $\{2004,2005,2006,2007,2008,2009,2010\}$; the

715 block effect constrains the permutations in the PERMANOVA by entering the model as a

716 "stratum."

717

\begin{tabular}{|r|r|r|r|r|r|r|}
\hline \multicolumn{1}{|c|}{ Parameter } & \multicolumn{1}{|c|}{ df } & \multicolumn{1}{|c|}{ SS } & \multicolumn{1}{c|}{ MS } & F (model) & \multicolumn{1}{|c|}{$\boldsymbol{r}^{2}$} & $\boldsymbol{P}(>\mathbf{F})$ \\
\hline Regeneration component & 3 & 8.1 & 2.70 & 20.66 & 0.32 & 0.001 \\
\hline Canopy manipulation treatment & 2 & 1.9 & 0.96 & 7.36 & 0.08 & 0.001 \\
\hline Year & 1 & 1.6 & 1.60 & 12.22 & 0.06 & 0.001 \\
\hline Regeneration component $\times$ & 6 & 2.7 & 0.46 & 3.49 & 0.11 & 0.001 \\
treatment & & & & & & \\
\hline Residuals & 83 & 10.9 & 0.13 & & 0.43 & \\
\hline Total & 95 & 25.2 & & & & \\
\hline
\end{tabular}

718 


\section{$720 \quad$ Figure legends}

721 Fig. 1. Conceptual model illustrating how seed banks (including spores and other propagules),

722 seed rain (also including spores and other propagules), and advance regeneration contribute to

723 plant species abundance in a recovering forest stand over time. Middle panel shows temporal

724 trends in relative abundance of species colonizing the forest floor following canopy

725 manipulations in 2005; the different line types illustrate relative abundances of different taxa.

726 Diagonal white parallelograms on the left show inputs; shaded parallelograms on the right show

727 outcomes.

728

729 Fig. 2. Composition and relative abundances of the seed rain, seed banks in 2004 and 2010,

730 understory layers and sapling layers in 2004 and 2010, and dynamics of forest understory species

731 between 2005 and 2009 in the hemlock control treatment. Star plots depict relative abundances

732 of the 14 most common genera in 2004 and 2010; seed rain relative abundances are summed

733 over 2005 to 2009 . Taxa are color-coded by genus and life form (trees in greens, shrubs in

734 oranges, forbs in blues, and graminoids in reds); see color wheel legend at upper left. For the

735 purposes of visualizing rare taxa clearly, all relative abundances were square-root-transformed

736 prior to plotting; note that this transformation disproportionately magnifies the relative

737 abundance of rare species. The scale bar at upper left indicates the length of a radius

738 corresponding to $100 \%$ composition of a given species (relative abundance $=1$ ). Note that no

739 graminoids appeared in the understory between 2005 and 2009. Graphs in the center illustrate

740 mean relative abundances ( \pm 1 S.D.) of the 14 most common genera in the two replicate plots

741 within each treatment. Although all treatment plots were censused yearly at approximately the

742 same time, the mean points are shown here slightly offset to allow the points and error bars to be 
743 distinguished. Taxa are grouped by life form (trees, shrubs, forbs, and graminoids), and color

744 coding is as shown in the color-wheel legend.

745

746 Fig. 3. Composition and relative abundances of the seed rain, seed banks in 2004 and 2010,

747 understory layers and sapling layers in 2004 and 2010, and dynamics of forest understory species

748 between 2005 and 2009 in the girdled treatment. Species codes, scales, and legends are as in

$749 \quad$ Fig. 1.

750

751 Fig. 4. Composition and relative abundances of the seed rain, seed banks in 2004 and 2010,

752 understory layers and sapling layers in 2004 and 2010, and dynamics of forest understory species

753 between 2005 and 2009 in the logged treatment. Species codes, scales, and legends are as in Fig. 7541.

755

756 Fig. 5. Ordination bi-plot of the changes in the seed bank ( $\boldsymbol{\nabla}: 2004$ versus 2010) and trajectories

757 of the seed rain $(\square)$, understory vegetation $(\boldsymbol{\Delta})$, and saplings $(\bullet)$ (2004-2010; replicates pooled

758 across blocks). The different colors represent the different treatments: blue - hemlock control;

759 dark yellow - girdled treatment; red - logged treatment, and the start and end of each trajectory

760 are identified. Dotted lines indicate seed dynamics (seed rain, seed bank) and solid lines indicate

761 standing vegetation The inset plot expands the lower right corner of the main bi-plot to more

762 clearly show the trajectories of the saplings and seed rain, which otherwise overlap extensively

763 in the main bi-plot. Species whose loadings are $>0.1$ are shown along the $x$ - and $y$-axes. 
765 Fig. 6. Mean numbers of germinating seedlings ( \pm 1 S.D.) in the upper $(0-10 \mathrm{~cm}$ depth) and

766 lower (10-20 cm depth) soil strata in the 2010 seed bank trial, pooled across all treatment types

767 and replicates. Means on left show the plants emerging from the upper $10 \mathrm{~cm}$ of the core; those

768 on the right show those emerging from the $10-20 \mathrm{~cm}$ depth. Taxa are grouped by trees (greens),

769 shrubs (oranges), forbs (blues), and graminoids (reds) and ordered within groups from most to

770 least abundant in the upper stratum. Asterisks indicate taxa that were identified in both the 2004

771 and 2010 seed banks.

772 
$774 \quad$ Fig. 1

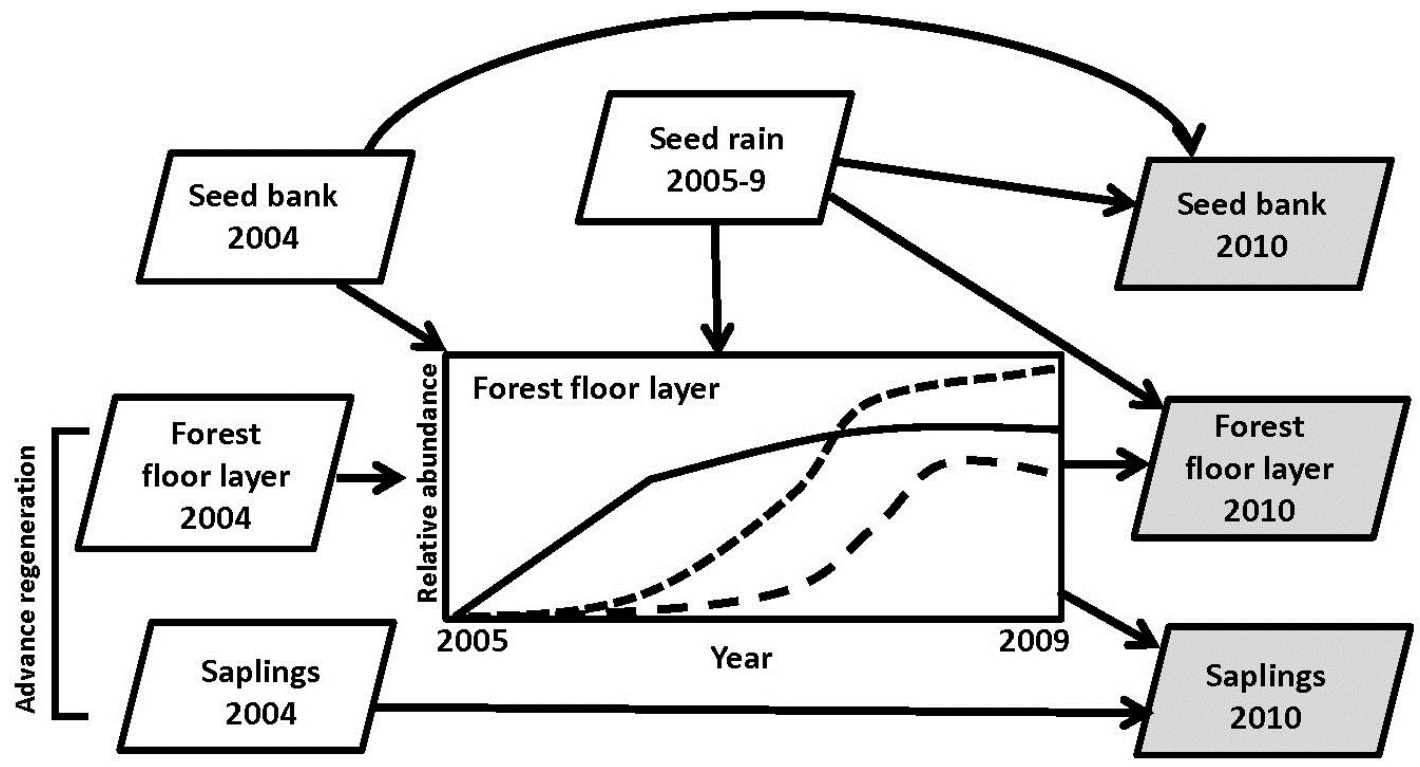


Fig. 2

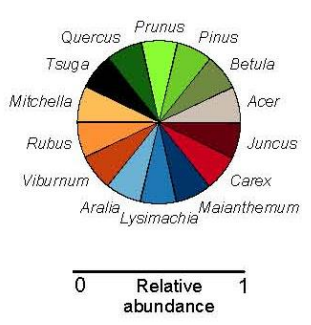

\section{Hemlock control plots}

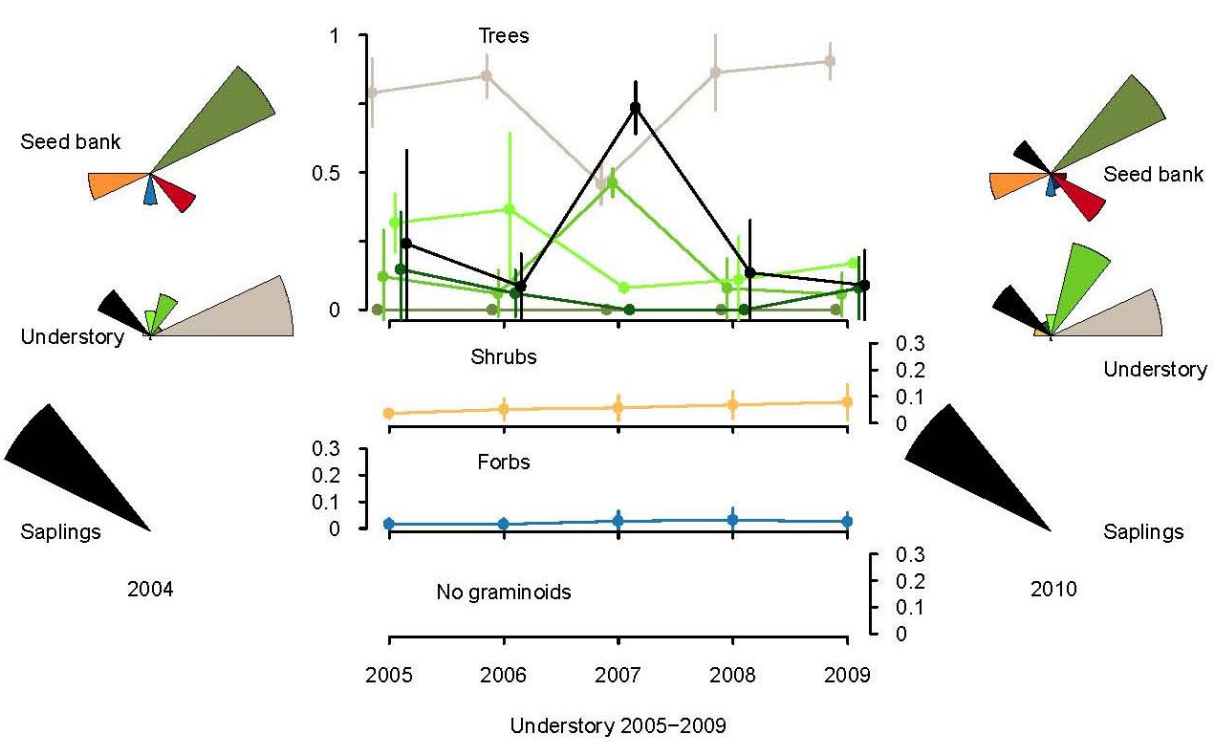


785 Fig. 3

786

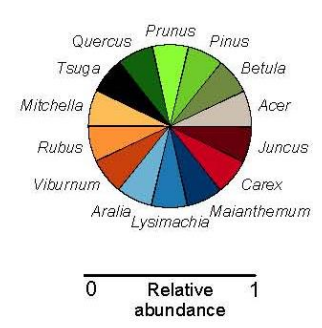

\section{Girdled plots}
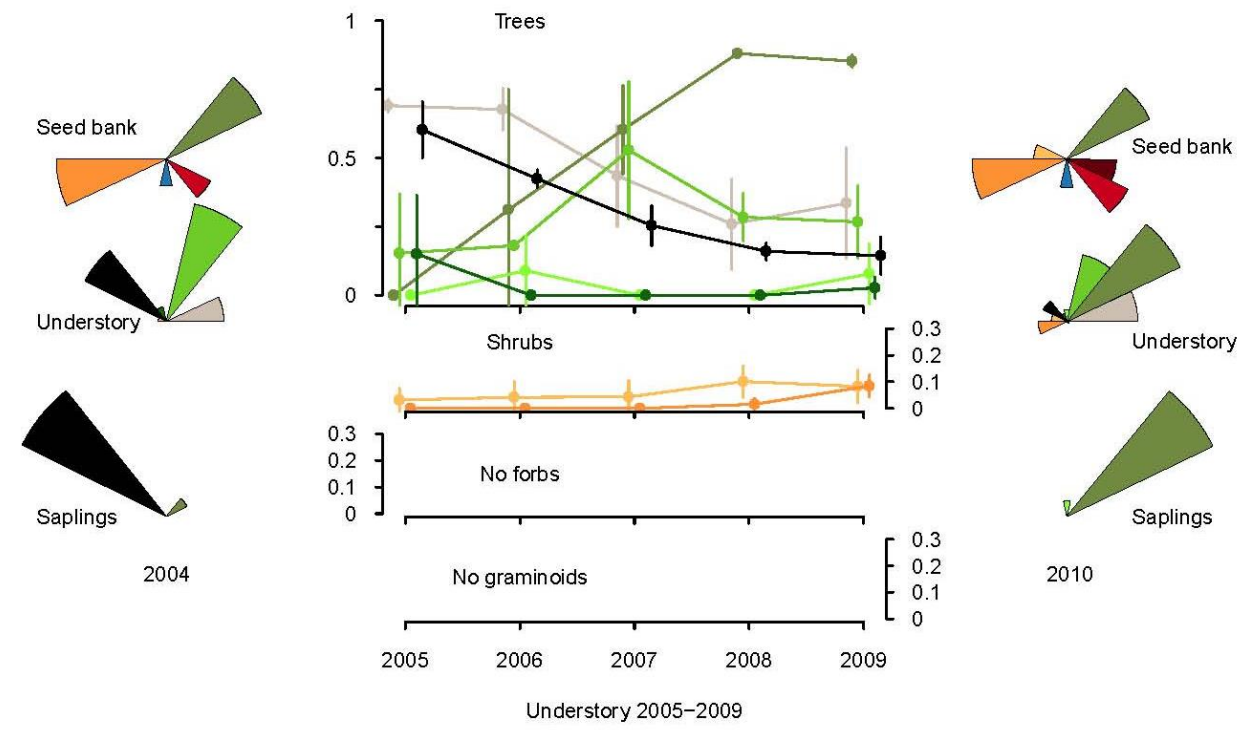

2010 
79

Fig. 4

792

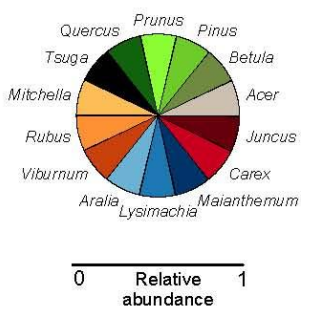

Logged plots
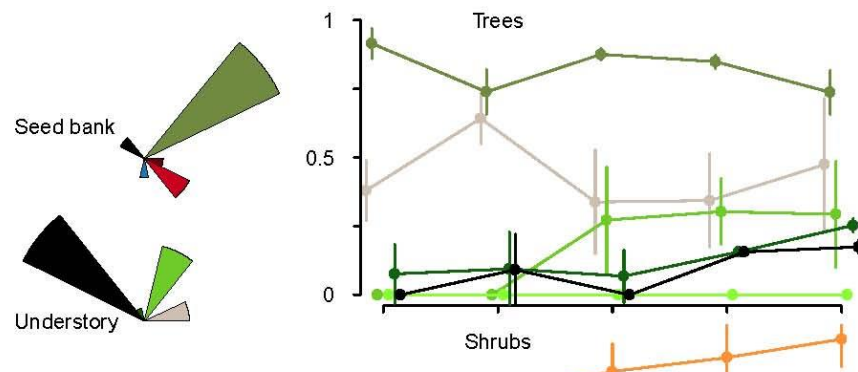

Seed rain 2005-2009

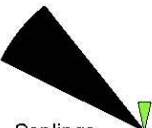

Saplings
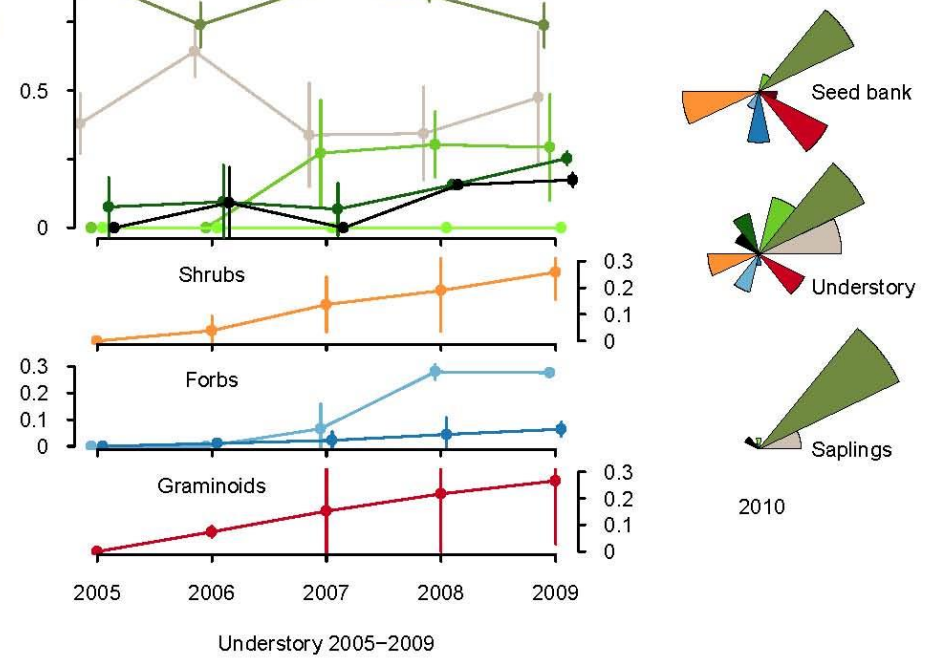

2010 
Fig. 5

\section{Principal component 1}

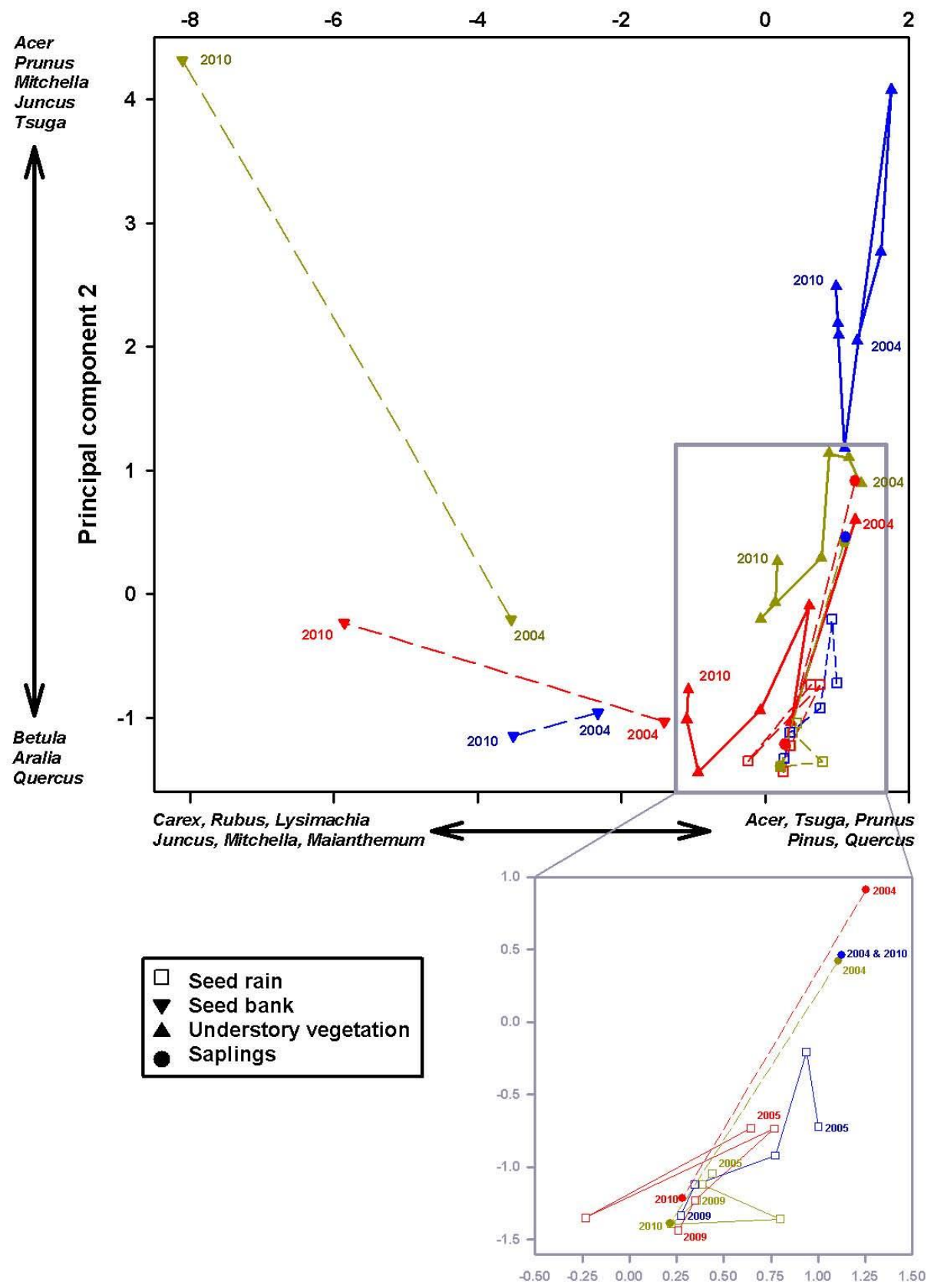


$798 \quad$ Fig. 6

799

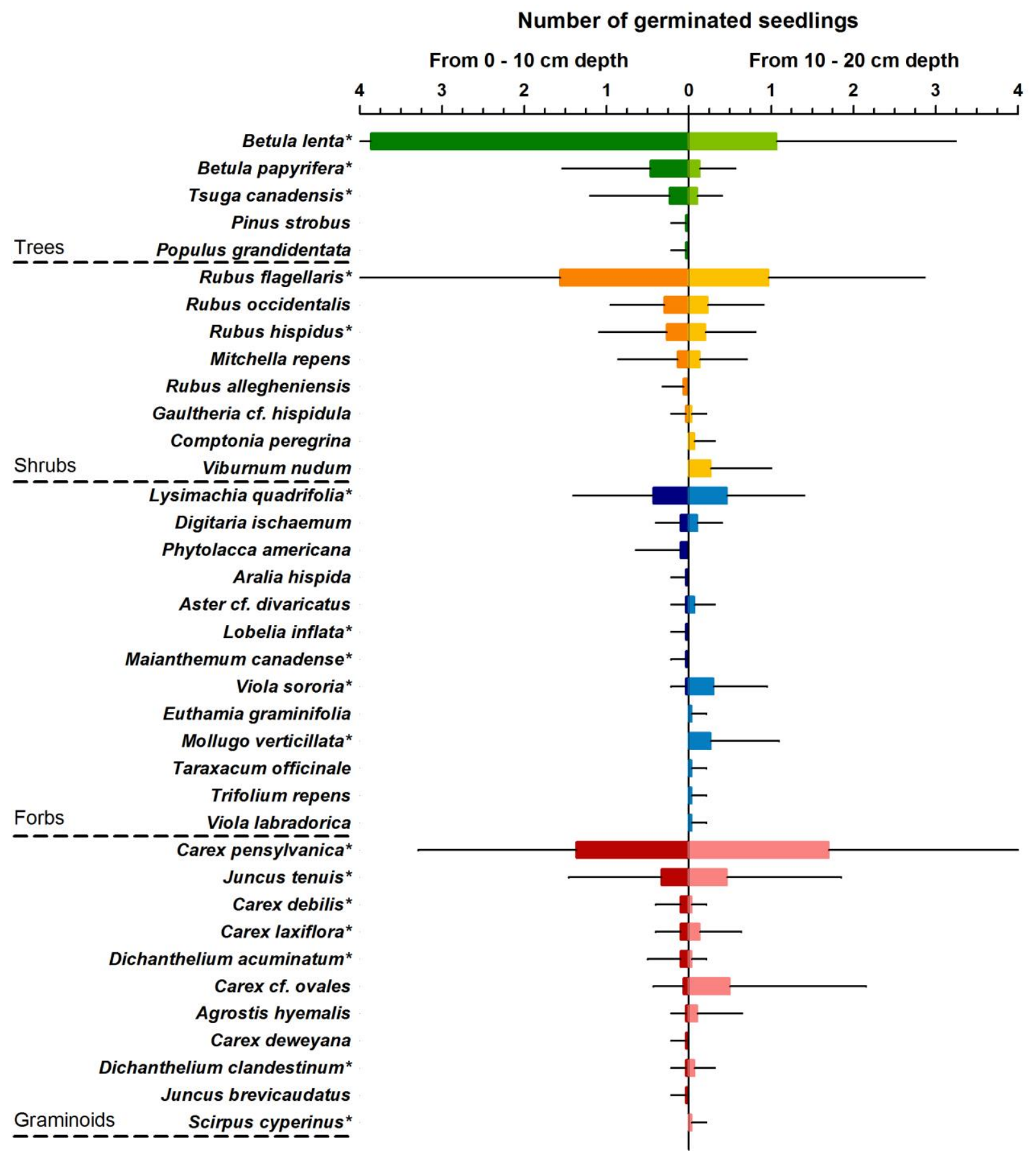

